Iranian Journal of Breast Diseases. 2021; 14(2):16-25.
Original Article

\section{Assessment of Serum Cystatin C Levels in Women with Breast Cancer Compared to the Control Group}

\author{
Esmaeili $F^{1}$, Pouresmaeil $V^{2,3^{*}}$, Amirabadi $A^{4}$ \\ ${ }^{1}$ Mashhad Medical Sciences Branch, Islamic Azad University, Mashhad, Iran \\ ${ }^{2}$ Department of Biochemistry, Mashhad Medical Sciences Branch, Islamic \\ Azad University, Mashhad, Iran \\ ${ }^{3}$ Innovative Medical Research Center, Mashhad Branch, Islamic Azad \\ University, Mashhad, Iran \\ ${ }^{4}$ Department of Oncology, Mashhad Medical Sciences, Mashhad, Iran
}

Receive: $23 / 2 / 2021$

Accepted: 30/6/2021

"Corresponding Author:

v.pouresmaeil@mshdiau.ac.ir

Ethics Approval:

IR.MSHDIAU.REC.1398.193

\begin{abstract}
Introduction: Breast cancer is the most common type of cancer in Iranian women, detected in $70 \%$ of cases when the disease has reached an advanced stage. The discovery of new diagnostic biomarkers is essential for the early detection of the disease. Cystatin $\mathrm{C}$ is a member of the cystatin family and a non-glycosylated, cysteine protease inhibitor that is also used as a functional marker of the kidney.

To evaluate the serum cystatin $\mathrm{C}$ level in women with breast cancer compared with a control group and to verify this in the pathophysiological data of the patients.
\end{abstract}

Methods: This study was carried out on 88 women (44 patients with breast cancer and 44 healthy controls) referred to Reza radiotherapy and oncology center, Mashhad, Iran, in 2020. After recording demographic information and clinical studies, the serum cystatin $\mathrm{C}$ level was measured using an ELISA kit, and the data were analyzed with SPSS version 22 .

Results: The mean age of healthy controls was 48.48 years and patients 52.32 years. The patients had a mean BMI of $29.52 \mathrm{~m}^{2} / \mathrm{kg}$, while the mean BMI for the controls was $24.37 \mathrm{~m}^{2} / \mathrm{kg}$. Our results showed that the mean serum cystatin C level $(\mathrm{ng} / \mathrm{ml})$ in breast cancer patients was $0.555 \pm 0.413$ versus $0.258 \pm 0.291$ in the control group $(\mathrm{P}<0.001)$. Serum cystatin $\mathrm{C}$ levels was correlated with cancer stage $(P=0.029)$, tumor size $(P=0.002)$, tumor grade $(P=0.001)$. In the analysis by $\mathrm{BMI}$, serum cystatin $\mathrm{C}$ level was significantly higher for both BMI $>25 \quad(\mathrm{P}<0.001)$ and $\mathrm{BMI} \leq 25 \quad(\mathrm{P}=0.017)$ in breast cancer patients compared with the controls. Cystatin $\mathrm{C}$ also increases significantly in patients over 50 years $(\mathrm{P}<0.001)$. No significant association was found between serum cystatin $\mathrm{C}$ level and lymph node involvement, estrogen receptor, progesterone receptor, or HER2. In the study of the ROC curve, sensitivity was equal to $65.9 \%$, specificity $86.4 \%$, positive predictive value $82.8 \%$ and negative predictive value $71.6 \%$.

Conclusion: Cystatin $\mathrm{C}$ plays an important role in the pathophysiology of breast cancer and can be used as a diagnostic biomarker.

Keywords: Cystatin C, Breast Cancer, Staging, Grade, Tumor 


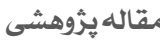

\section{بررسى سطح سرمى سيستاتين C در زنان مبتلا به سرطان بستان در مقايسه با}

كروه شاهد

فاطمه اسماعيلى'، وحيد يوراسماعيل זوَ":، امير امير آبادى"

'دانشجوى دكترى عمومى، دانشكده يزشكى، دانشكاه آزاد اسلامى مشهيد، ايران

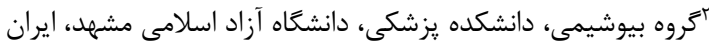

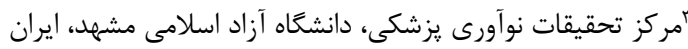

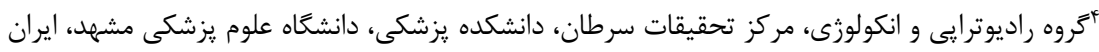

فصلنامه بيمارى هاى بستان ايران

$1 \varepsilon \cdot ? 1 \varepsilon(Y): 17-r 0$
جكيده

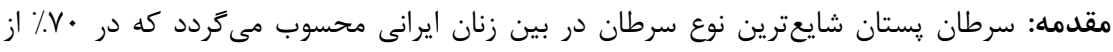

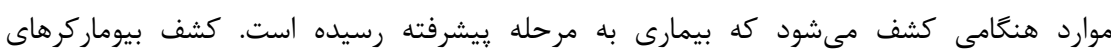

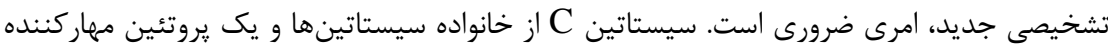

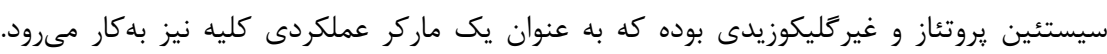

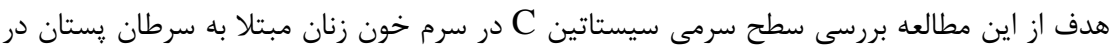

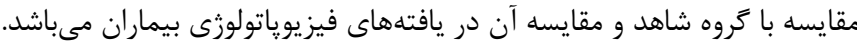

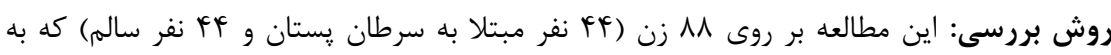

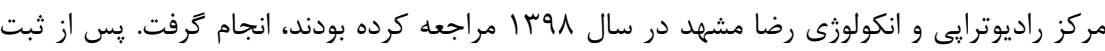

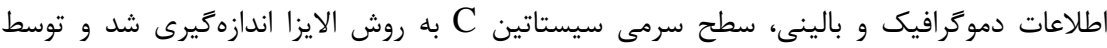
نرمافزار SPSS.V22 S تحليل شد.

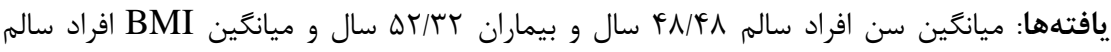

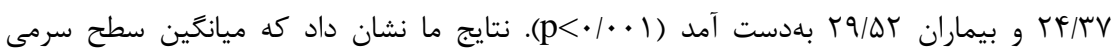

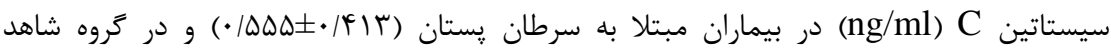

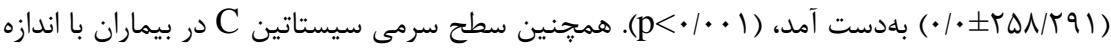

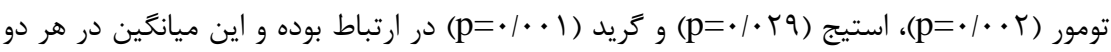

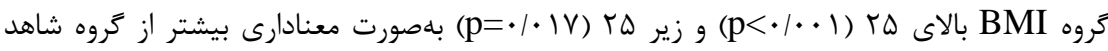

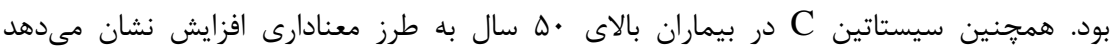

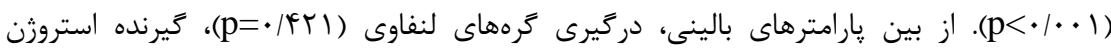

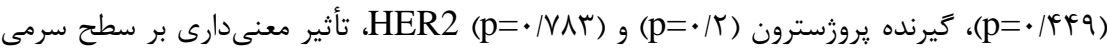

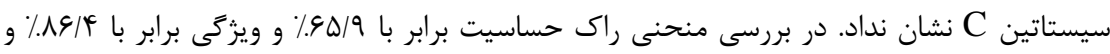

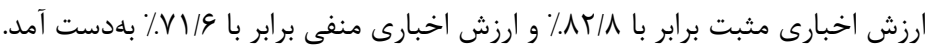
نتيجه كيرى: سيستاتين C نقش مهمى در فيزيوياتولوزى سرطان يستان دارد كه مىتواند به عنوان بك بيوماركر تشخيصى مورد استفاده قرار كيرد. أوازههاى كليدى: سيستاتين C، سرطان بستان، استيج، كريد، تومور

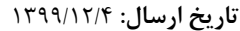

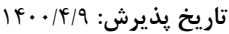

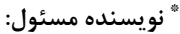
v.pouresmaeil@mshdiau.ac.ir 
سال، يكسان است (تقريباً مقدمه

مطالعه حاضر بررسى سطح سرمى سيستاتين C در سرم

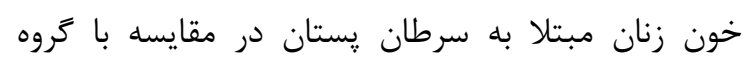

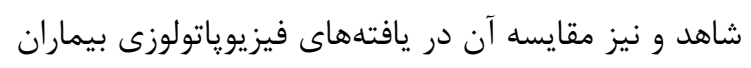
مىباشد.

\section{مواد و روشها}

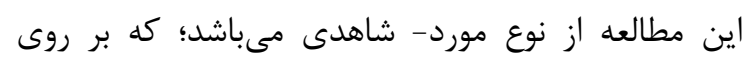

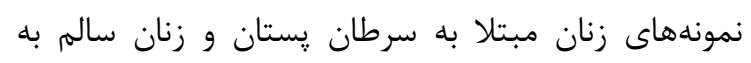

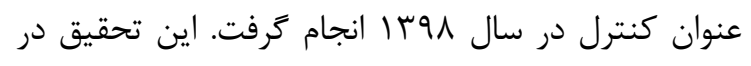

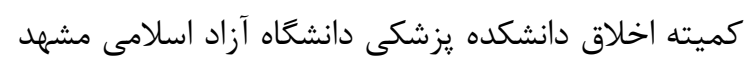

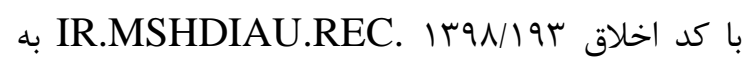
تصويب رسيده است. با توجه به معيارهاى خروج از مطالعه كه براى بيماران

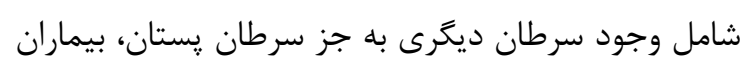

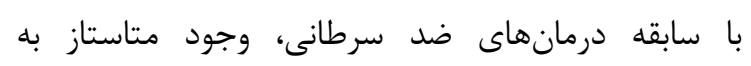

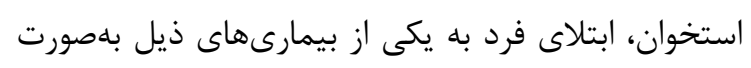

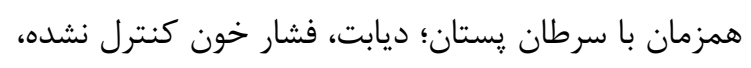

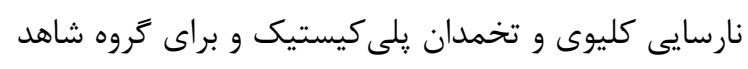

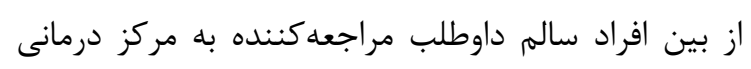

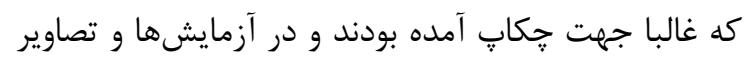

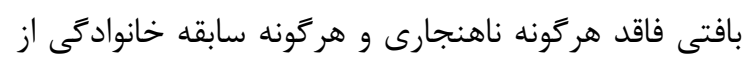
هر نوع سرطان بودند، انتخاب شدند.

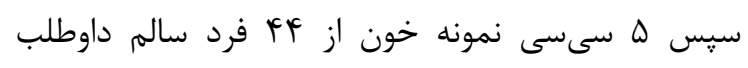

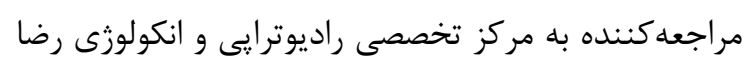

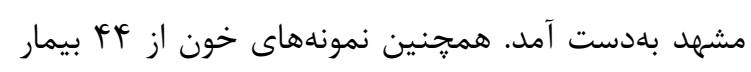

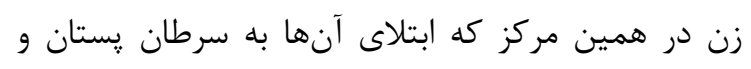

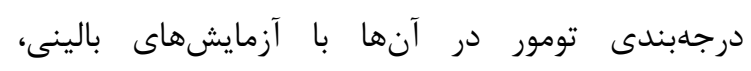
آزمايشكاهى و راديولوزيك مورد بررسى و تائيد قرار كرفته

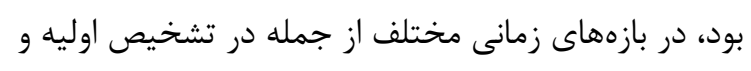

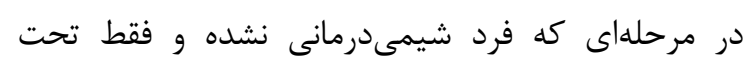

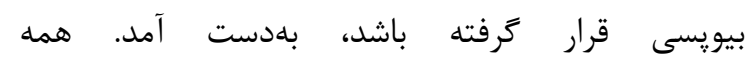
شركت كنندگان در اين مطالعه فرم رضايت آكاهانه كتبى

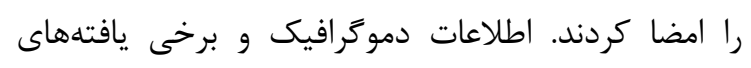

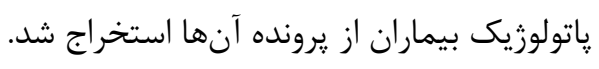

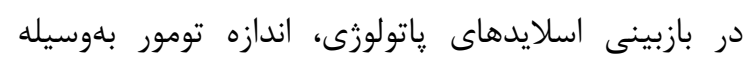

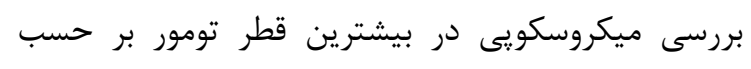

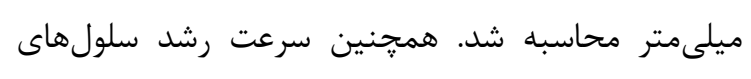

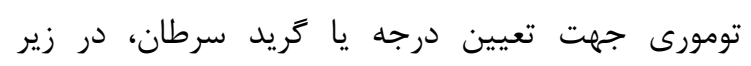

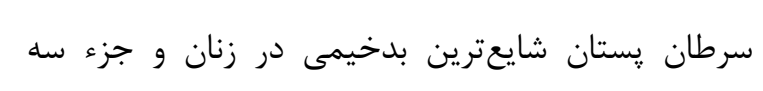

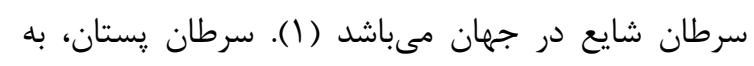

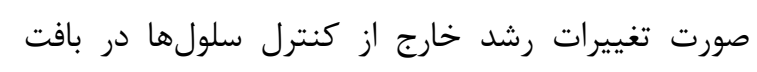

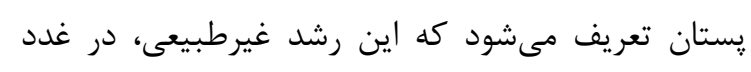

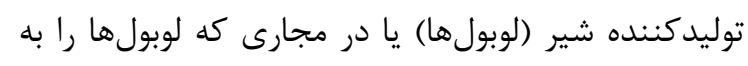

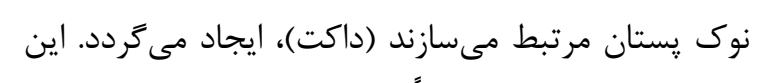
بيمارى هتروزن كه عمدتاً به استخوان متاستاز مىدهدي،

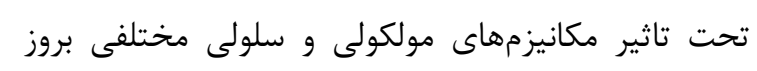
مى كند كه تا حدودى ناشناخته باقى ماندهاند.

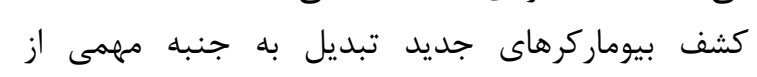

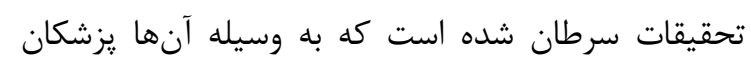

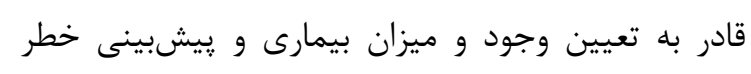

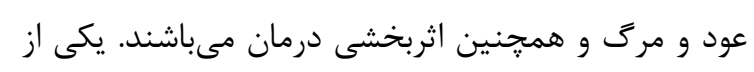

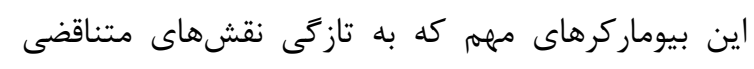

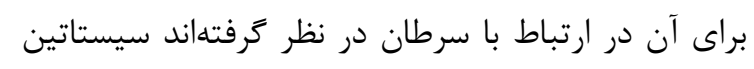
C

يكى عيب بزرى بيوماركرهاى تومورى، نياز به تهيديه

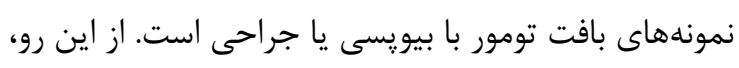

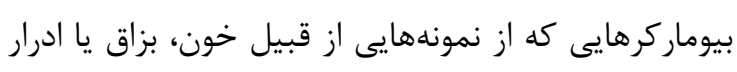

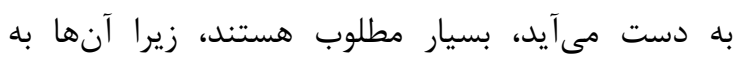
راحتى قابل دسترس بوده و امكان ارزيابى يِيوسته آنها

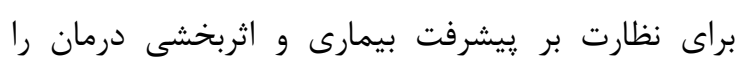

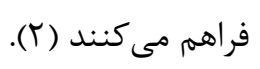

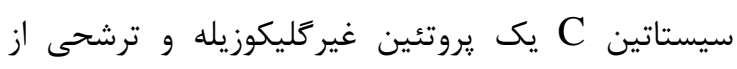

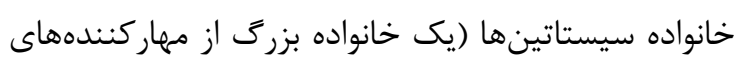

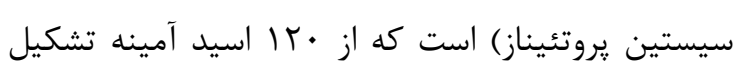

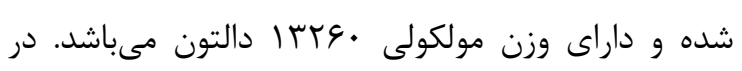
انسان، سيستاتين C سرمى به طور يیوسته توسط تمام

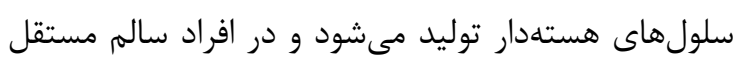
از سن، توده عضلانى يا شاخص توده بدنى مى باشد (بار)

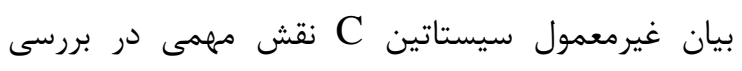

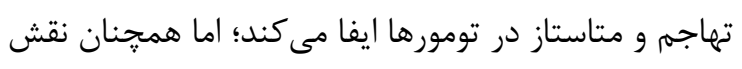

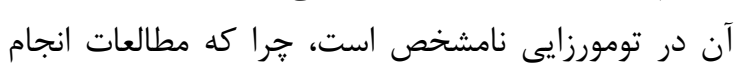

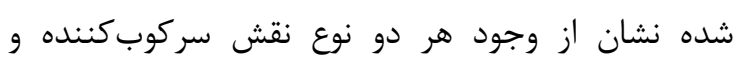

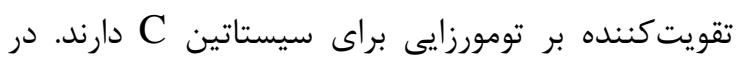

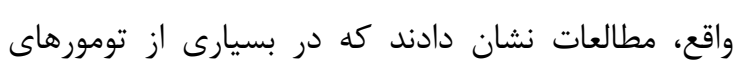

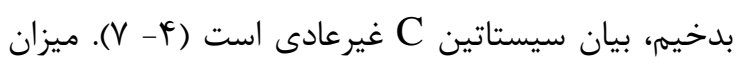

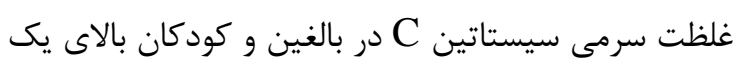


نرمال بودن از روشهاى يارامترى مناسب مانند آزمون

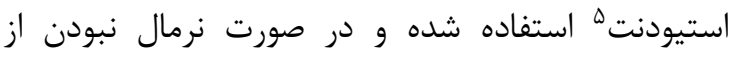

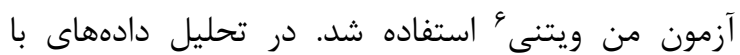

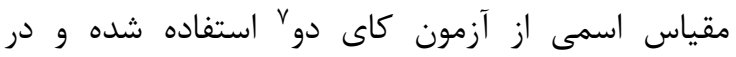

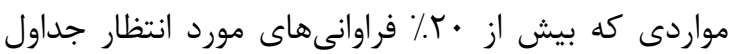

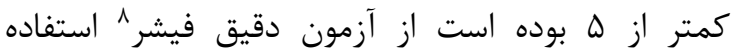

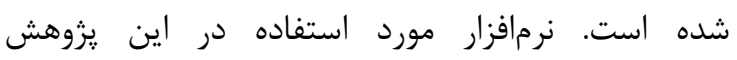
IBM-SPSS v.22 بوده و سطح معنى دارى آزمونها تردها كمتر از هـ در نظر كرفته شد. در نتايج، مقادير كمتر از

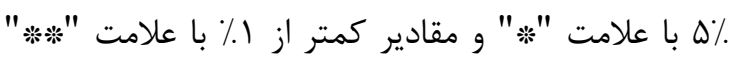
مشخص شدهاند.

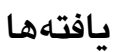
اين مطالعه با هدف بررسى سطح سرمى سيستاتين C در خون زنان مبتلا به سرطان يستان در مقايسه با كروهان

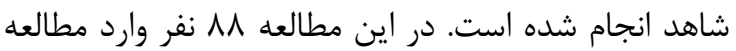

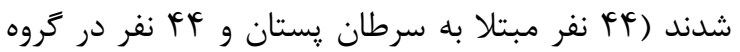

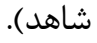

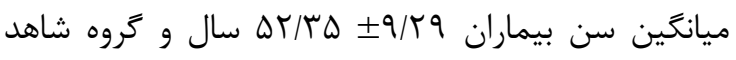
FN/FN E IF/FV

$$
\text { معنادارى وجود نداشت (ه •/p) }
$$

با توجه به جدول ا يافتههاى مطالعه ما نشان داد كه

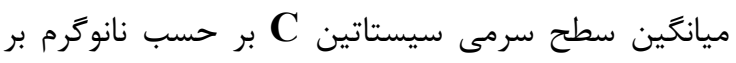

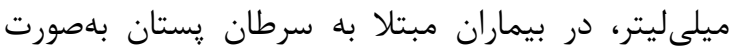

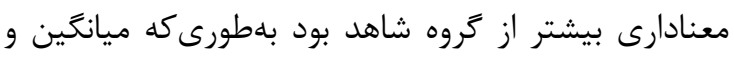

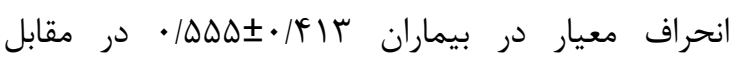
| همجنين ميانگين BMI در بيماران مبتلا به سرطان

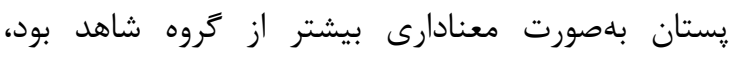

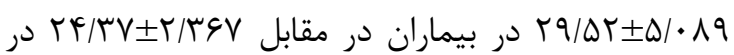

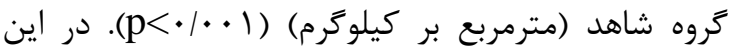

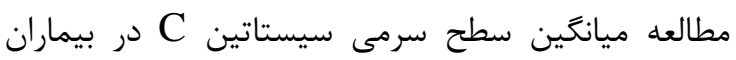

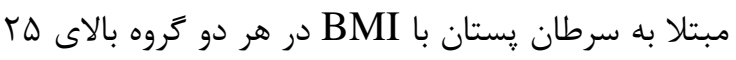

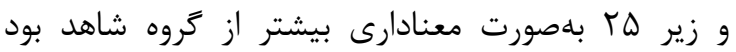

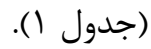

\footnotetext{
${ }^{5}$ Student $t$ Test

${ }^{6}$ Mann-Whithney

${ }^{7}$ Pearson Chi-Square

${ }^{8}$ Fishers Exact Test
}

ميكروسكوب بررسى شد. بعد از نيم ساعت انكوبه شدن

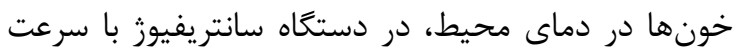

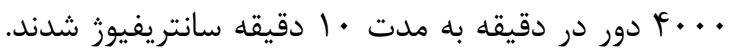

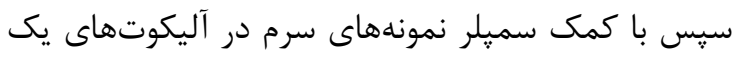

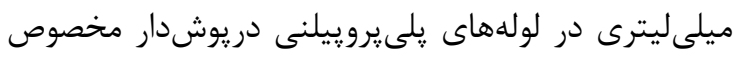

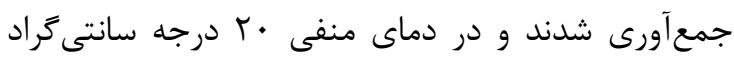
نكَهدارى شدند. بر روى نمونههاى سرم الايزاى ساندويج دريج

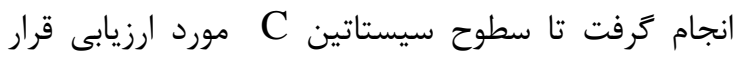
كيرد. آنتىبادى يلى كلونال انسانى براى سيستاتين C در كف إنف

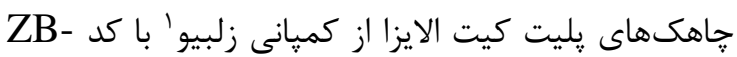

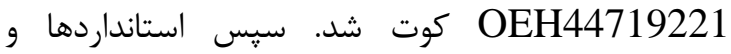
نمونهها به خاهكها اضافه شده و به مدت يك ساعت در

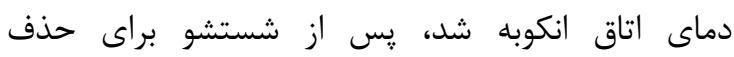

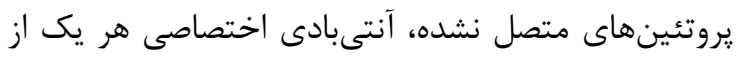

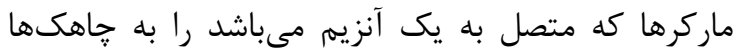

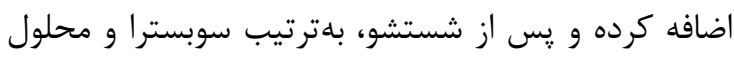
توقف اضافه شد. در نهايت جذب خاهك نها در طول موج

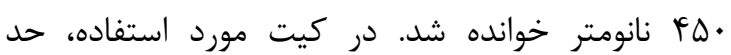

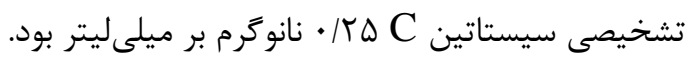

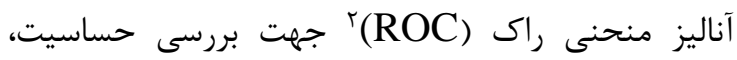

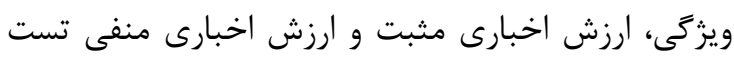

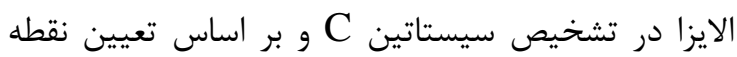

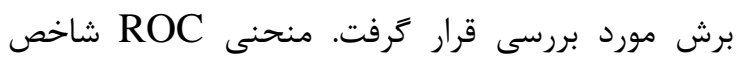

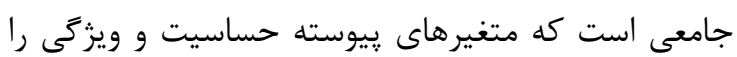
نشان مىدهد و مىتواند بهصورت بصرى ارتباطات بين

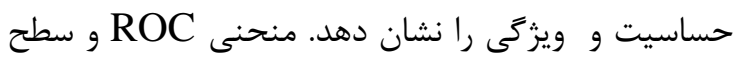

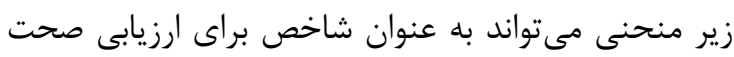

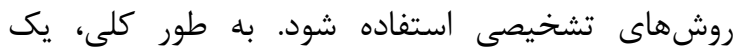

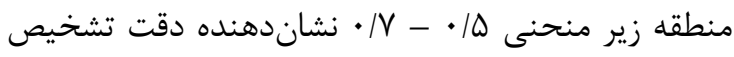

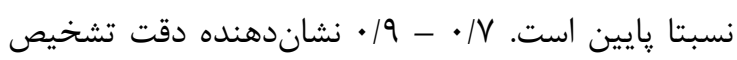

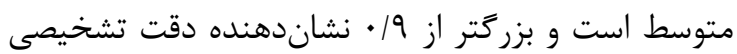

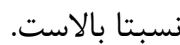

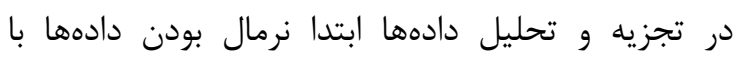

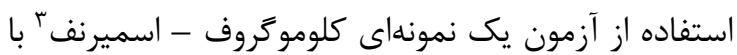
اصلاح لى لى فرس ب مورد بررسى قراركرفته كه با تأييد

\footnotetext{
${ }^{1}$ Zellbio

${ }^{2}$ Receiver-operating Characteristic

${ }^{3}$ Kolmogorov-Smirnov

${ }^{4}$ Lilliefors
} 


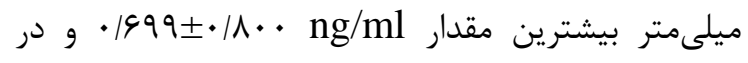

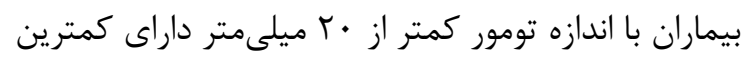

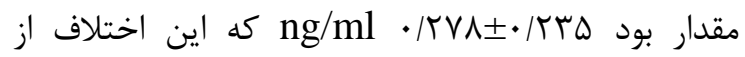

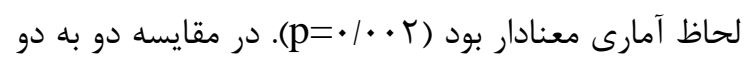

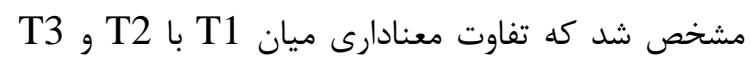

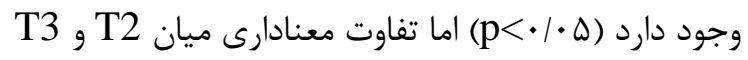
ديده نشد (جدول r، شكل a la).
نتايج همجنين نشان داد كه ميانگين سطح سرمى

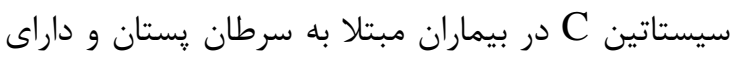

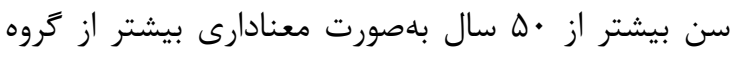

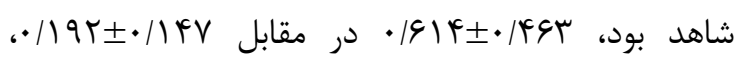

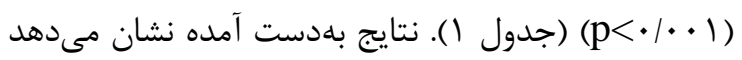

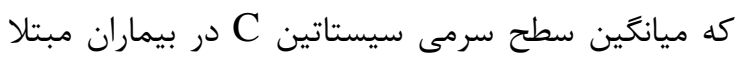

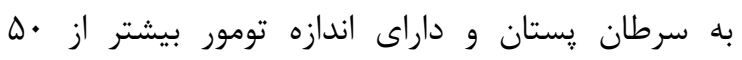

جدول ا: ميانكَين سطح سرمى سيستاتين C در متغيرهاى اندازمَّيرى شده در مبتلايان به سرطان يستان و كَروه شاهد

\begin{tabular}{|c|c|c|c|}
\hline P value & سرطان يستان & شاهد & 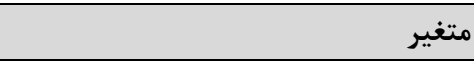 \\
\hline $\mathrm{P}<\cdot / \cdot \cdot 1$ & $\cdot / \cdot \pm \Delta \Delta \Delta / \& \mid r$ & $\cdot / \cdot \pm r \Delta \Lambda / r q 1$ & سطح سرمى سيستاتين C(ng/ml) \\
\hline $\mathrm{P}<\cdot / \cdot \cdot 1$ & $r q / \Delta \pm \Delta r / \cdot \wedge q$ & $T Y / T \pm \Gamma V / T S V$ & BMI \\
\hline $\mathrm{P}=\cdot / \cdot 1 \mathrm{~V}$ & $\cdot / \cdot \pm q \cdot \Delta / r \cdot 9 r$ & $\cdot / \cdot \pm r T r / r \Delta g \Lambda$ & سطح سر مى سيستاتين C در BMI>25 \\
\hline $\mathrm{P}<\cdot / \cdot \cdot 1$ & $\cdot 1 \cdot \pm \Delta F \Delta / F r T q$ & $\cdot / \cdot \pm 1 \wedge \Lambda / I \vee 9 \vee$ & سطح سر مى سيستاتين C در BMI>25 \\
\hline $\mathrm{P}<\cdot / \cdot \cdot 1$ & $\cdot|\cdot \pm q| f / \& q \mu \mid$ & $\cdot / \cdot \pm 19 r / 1$ FVq & سطح سرمى سيستاتين C سن بالاى •ه سال \\
\hline $\mathrm{P}=\cdot / 1 \cdot 1$ & $\cdot|F \Delta I \pm \cdot / 4 a T|$ & - /MFFE./rqqT & سطح سرمى سيستاتين C سن زير •ه سال \\
\hline
\end{tabular}

جدول r: ميانغين و انحراف معيار سيستاتين C در بيماران مبتلا به سرطان يستان بر اساس اندازه تومور، مرحله و درجه سرطان

\begin{tabular}{|c|c|c|c|c|c|}
\hline $\begin{array}{c}\text { P-value } \\
\text { (Kruskal Wallis test) }\end{array}$ & آماره آزمون & انحراف معيار & ميانگين سيستاتين C & 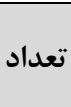 & متغير \\
\hline \multirow{4}{*}{$\cdot 1 \cdot \cdot r$} & \multirow{4}{*}{$I T / T \Delta$} & • ITHAI & $\cdot / T V A$ & it & (تومور كمتر از • T1 \\
\hline & & $\cdot / r \cdot 4 q$ & $.194 \Delta$ & TF & 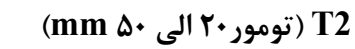 \\
\hline & & $\cdot / \Lambda \cdots+$ & .1999 & $\wedge$ & T3 (تومور بيشتر از • Dm (mm) \\
\hline & & . & $\cdot / \Delta \Delta \Delta$ & fF & كل \\
\hline \multirow{4}{*}{$\cdot 1 \cdot \mathrm{rq}$} & \multirow{4}{*}{$V / 1$} & . ITEVI & $\cdot / r V A$ & 9 & Iاستيج I \\
\hline & & - ITFFA & $\cdot 1 \Delta \vee 9$ & ra & II استيج \\
\hline & & . 19994 & - MAT & $1 \cdot$ & III استيج \\
\hline & & . MITL & $\cdot / \Delta \Delta \Delta$ & fF & 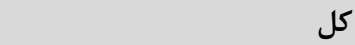 \\
\hline \multirow{4}{*}{$\cdot 1 \cdot \cdot 1$} & \multirow{4}{*}{$1 r / 4 q$} & $\cdot / \cdot T \& \Delta$ & $\cdot 1 \cdot \mathrm{VV}$ & r & تريد I I I \\
\hline & &.$/ 4019$ & س & rq & تريد II \\
\hline & & . ITTVG & $\cdot$ /VTV & it & تريد III \\
\hline & & DITIT & $\cdot / \Delta \Delta \Delta$ & fF & 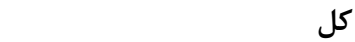 \\
\hline
\end{tabular}

سرمى سيستاتين C از نظر گريد (درجه) در بيماران مبتلا

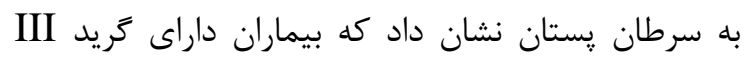

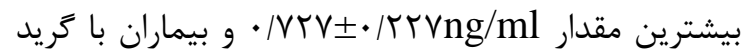

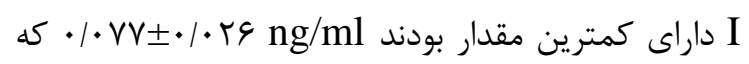

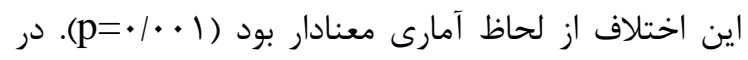
مقايسه دو به دو مشخص شد كه تفاوت معنادارى ميان

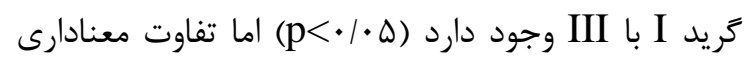

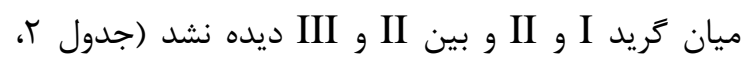
شكل lc) همجنين نتايج نشان داد كه ميانگين مصرف

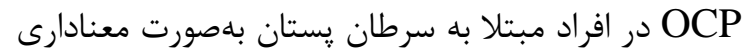

ميانخين سطح سرمى سيستاتين C از نظر استيج (مرحله) در بيماران مبتلا به سرطان يستان نشان داد كه بيماران

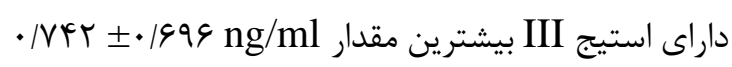
و بيماران با استيج I داراى كمترين مقدار بودند ng/ml / FVA • / T FV

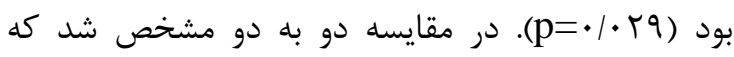

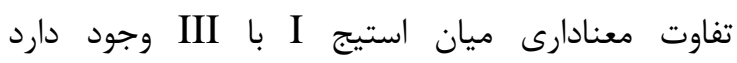

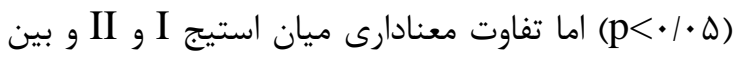

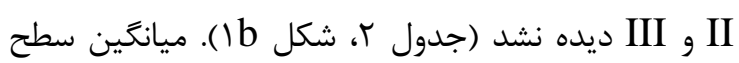




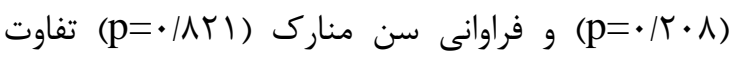

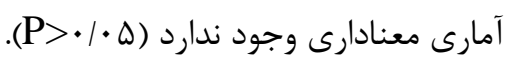

با توجه به جدول r و منحنى راك (شكل r)، حساسيت

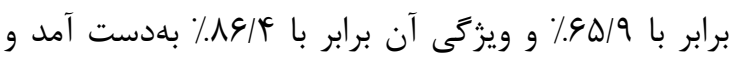

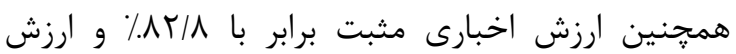
اخبارى منفى برابر با VI/9\% بهدست آمد.

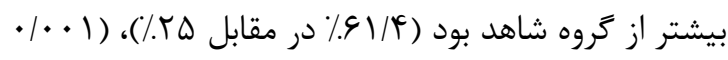
. $\mathrm{p}=$ علاوه بر اين نتايج نشان داد كه ميانگين سطح سرمى

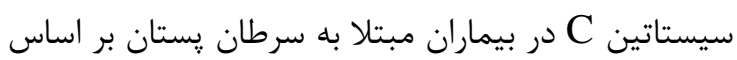
ER

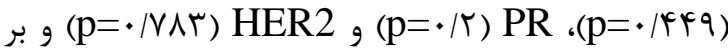

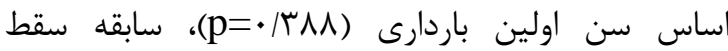
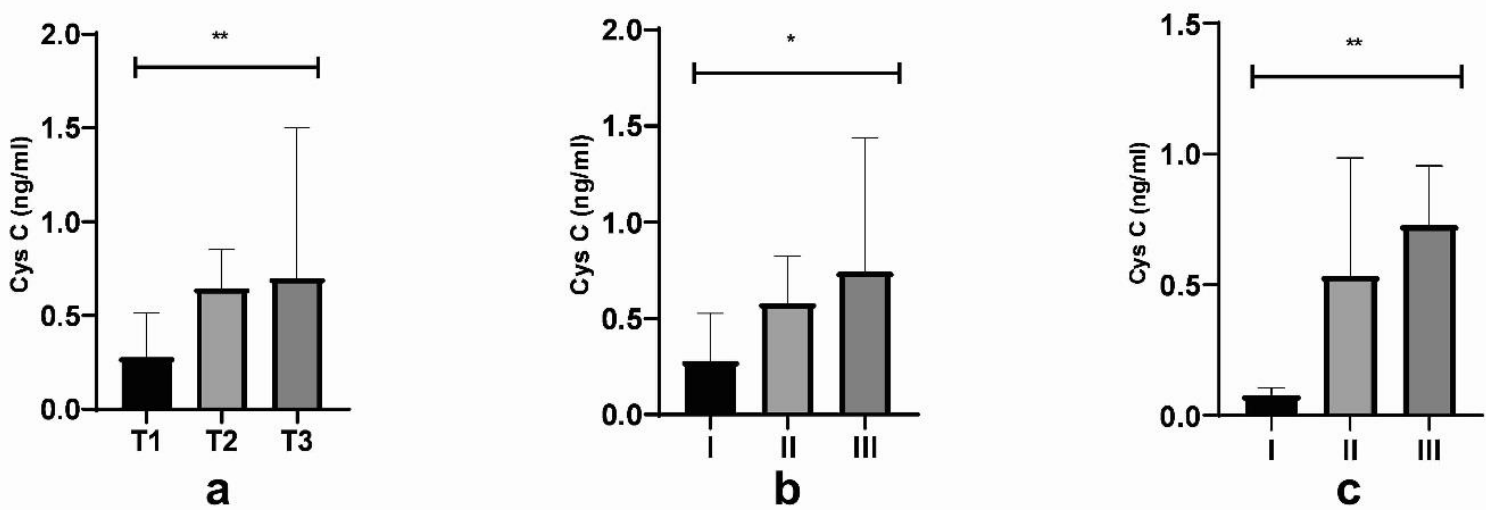

شكل ا: ميانگَين و انحراف معيار سيستاتين C در بيماران مبتلا به سرطان يستان بر اساس اندازه تومور(a)، استيج (b) و كريد سرطان (p-value=0/002; p-value=0/029; p-value=0/001). .(c)

\begin{tabular}{|c|c|c|c|c|}
\hline \multicolumn{5}{|c|}{ جدول بّ: سطح زير منحنى راك سيستاتين C در تشخيص سرطان يستان } \\
\hline \multicolumn{2}{|c|}{ 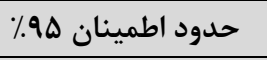 } & \multirow{2}{*}{ معنادارى } & \multirow{2}{*}{ خطاى استاندارد } & \multirow{2}{*}{ سطح زير منحنى } \\
\hline حد بالا & حد يايين & & & \\
\hline$\cdot|\lambda \Lambda|$ & $\cdot 19 \wedge \Delta$ & $.1 \cdot .1$ & $\cdot 1 \cdot \Delta$. & - /VAr \\
\hline
\end{tabular}

ROC Curve

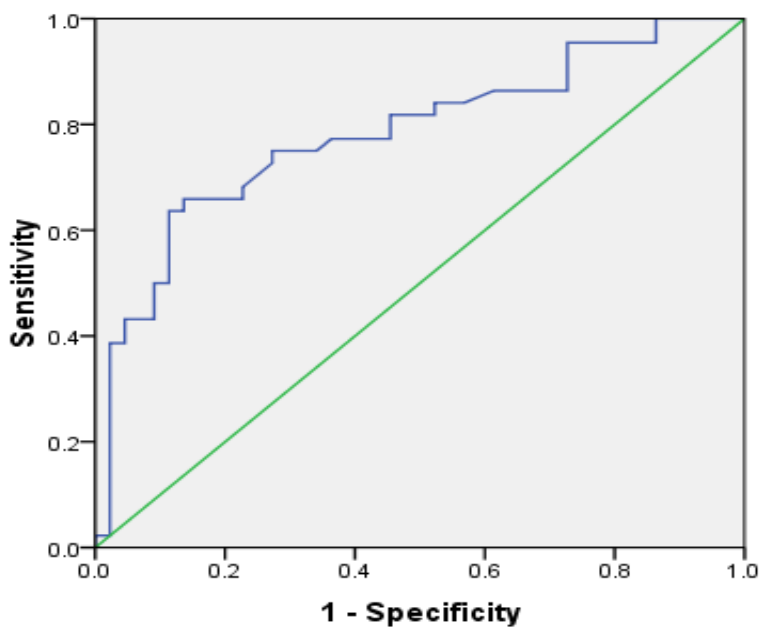

شكل r: منحنى راك سيستاتين C در تشخيص سرطان يستان 
در افراد سالم از سن و شاخص توده بدنى مستقل است

در مطالعه ما با توجه به اينكه ميانكين سطح سرمى

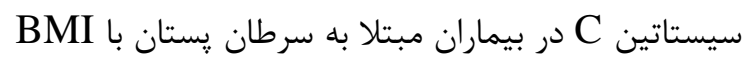

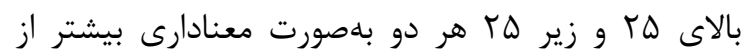

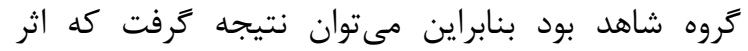

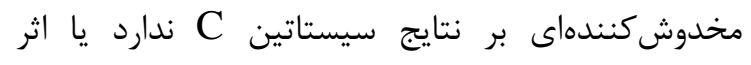

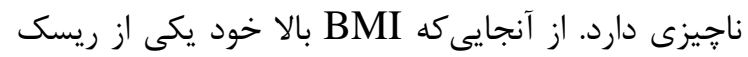

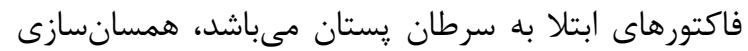
از نظر BMI در ابتداى مطالعه و با حجم نمونه كم، كارى سئل بسيار دشوار بود. مطالعه حاضر اولين مطالعه در ايران مىباشد كه رابطه سطح سرمى سيستاتين C و سرطان يستان را مورد

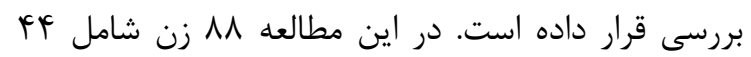

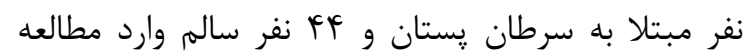
شدند. يافتههاى مطالعه ما نشان داد كه ميانگين سطح

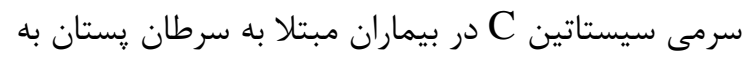

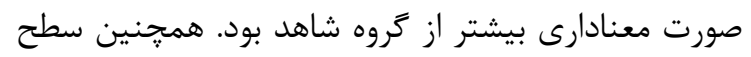
سرمى سيستاتين C در بيماران با اندازه تومور استيج و و

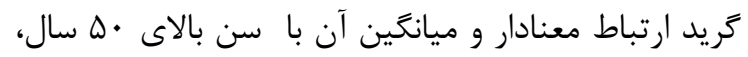

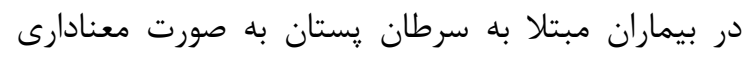

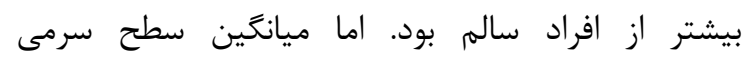

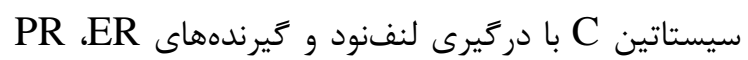

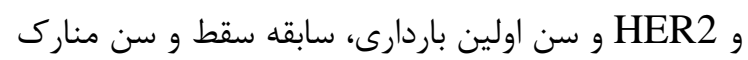

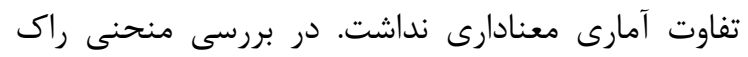

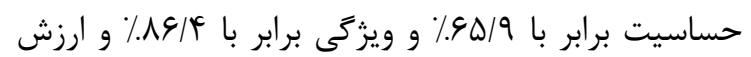

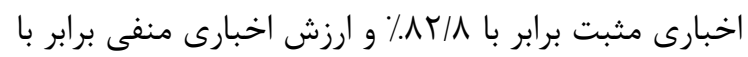

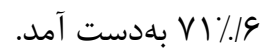

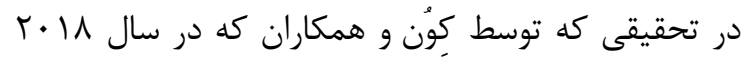
در بيمارستان دانشكاه اينها كره جنوبى با عنوان لابيان

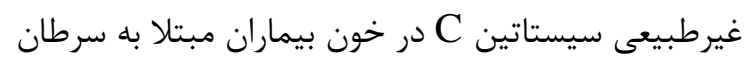
يستان يك نشانگر مناسب براى نظارت بر تومور استه

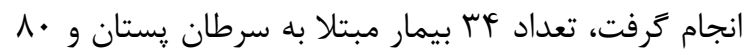
داوطلب سالم در يك مطالعه مورد-شاهدى بررسى شدند.

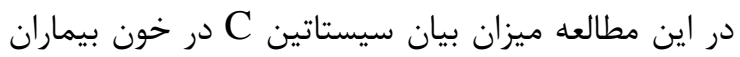

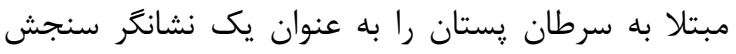

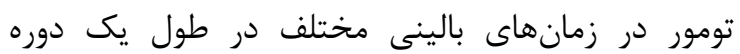

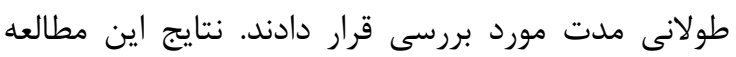

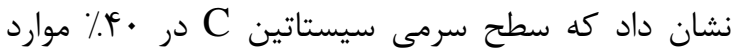

\section{بحث}

سرطان پِتان حدود يك سوم سرطانهاى زنان را تشكيل

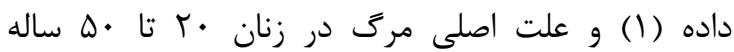
مىباشد. سرطان يستان نه تنها با هورمونهاى خاص يا دان

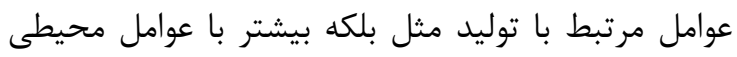

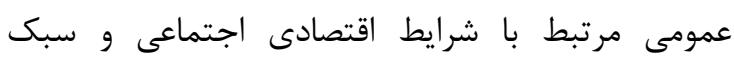
زندگى (سيكار كشيدن، استرس، ورزش بدنى و بخصوص عادات غذايى) ارتباط دارد (9). (9).

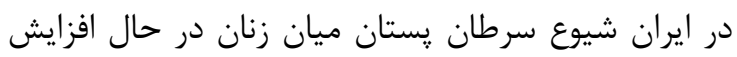
است و رتبه نخست را بين سرطانهاى زنان دان دارد. بان دان دان إنان

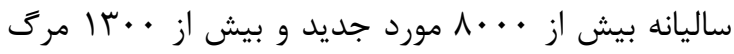
براى هر سال (•) (1) (1). ميزان بقاى كمتر بيماران سرطان يستان در كشورهاى كم توسعه يافته را ميىتوان بلهور

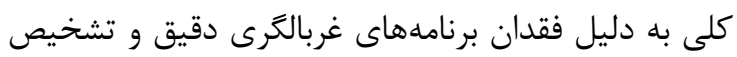

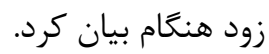

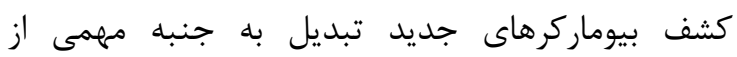
تحقيقات سرطان شده است كه به وسيله آنها يزشكان

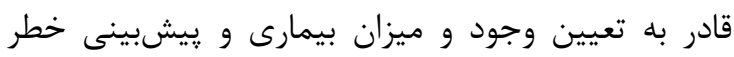

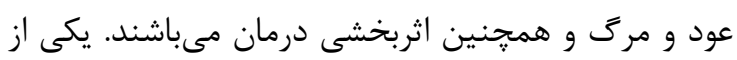

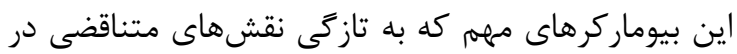

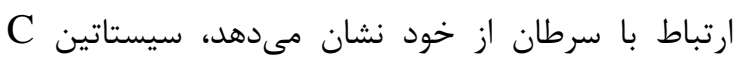

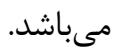
سيستاتين C يك يروتئين ممانعت كننده سيستئين يروتئاز و غيركليكوزيدى مىباشد كه در تمام سلولهاى بروني

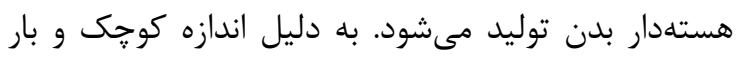

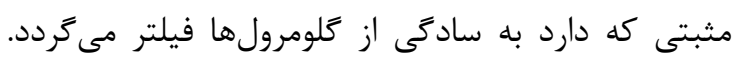

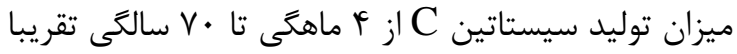

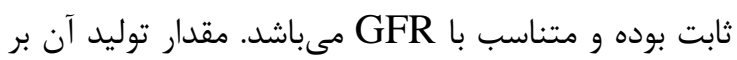

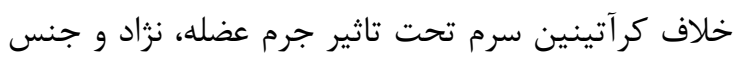

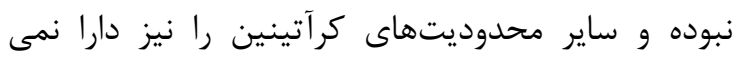
باشد.

مشخص شده است كه شاخص توده بدن بالا (BMI) با

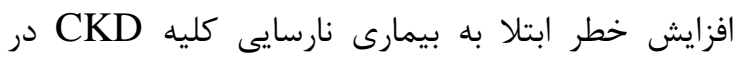

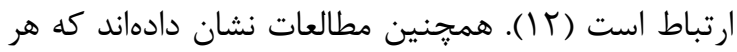

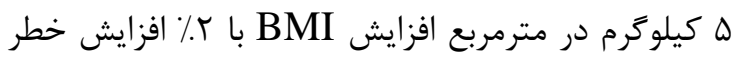

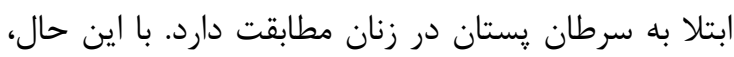

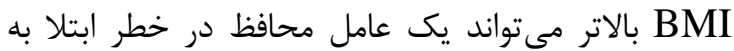

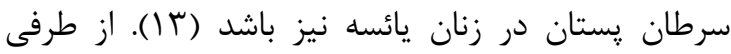

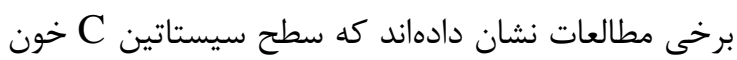


سطح بيان سيستاتين M يا C بين كارسينوم يستان با دركيرى غدد لنفاوى مثبت و منفى تفاوت معنى دارى باني

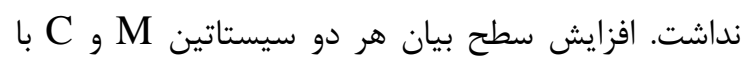
اندازه تومور بزركتر ارتباط معنى دارى داشت. mRNA

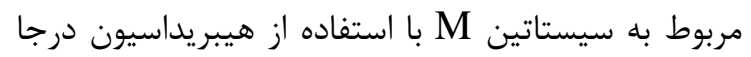
در سلولهاى سرطان يستان اوليه و متاستاتيك تشخيص

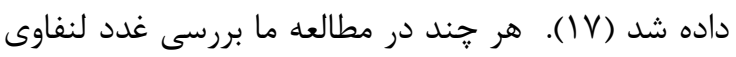

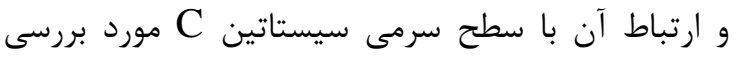

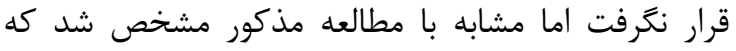

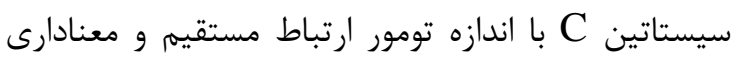
دارد. در مطالعه مرورى كه توسط لتو و همكاران در سال

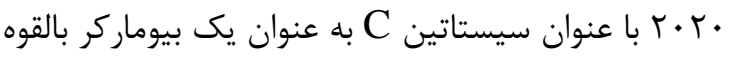
״يشبينى در سرطان يستان انجام شده است. از مطالعات

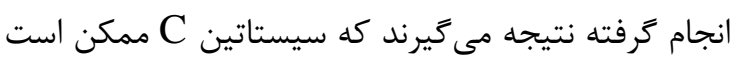

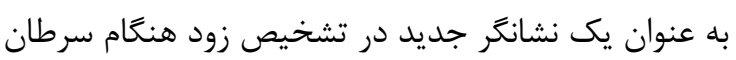

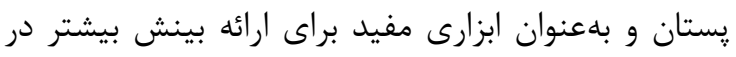

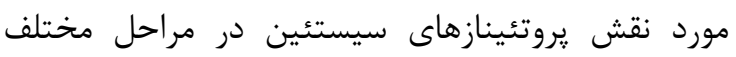

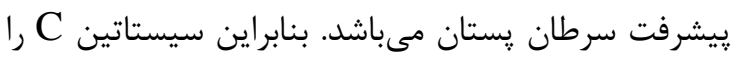

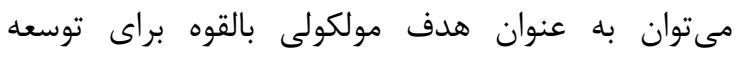

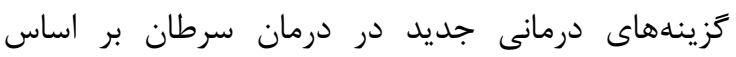
مهاركنندهاى يروتئيناز دانست (1) (1).

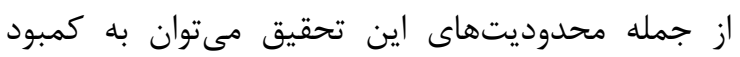

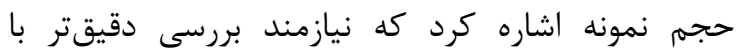

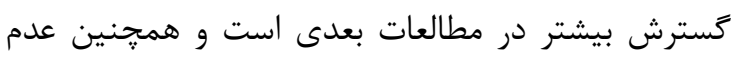

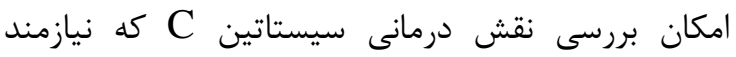

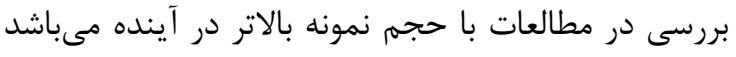

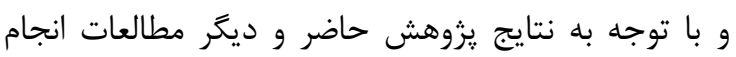

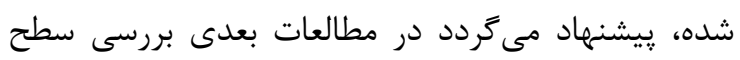
سرمى سيستاتين C در تومورها و مقايسه تغييرات آن قبل و بعد از جراحى يا شيمىدرمانى انجام يذيرد.

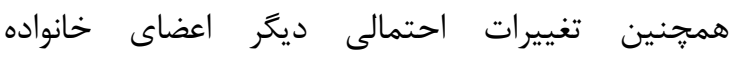
سيستاتينها نيز مورد بررسى قرار كيرد.

\section{نتيجه كيرى}

نتايج مطالعه ما نشان داد كه سطح سرمى سيستاتين لنسئ

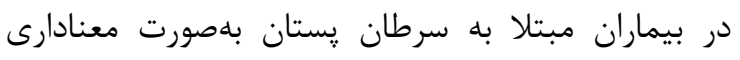

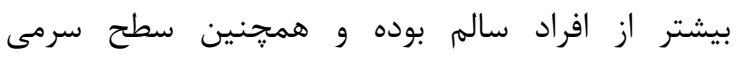

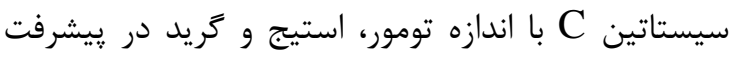

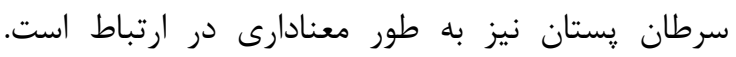

سرطان يستان افزايش مىيابد و اين افزايش وابسته به حجم تومور مىباشد (ه (1). يافتههاى مطالعه مذكور كاملاً همسو با يافتههاى مطالعه ما مىباشد. در مطالعه ما نيز

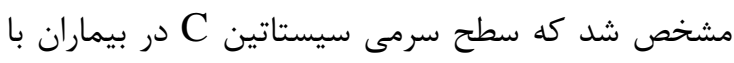

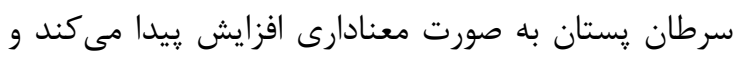
همجنين ارتباط معنادارى با اندازه تومور در بيماران دارد. در تحقيقى كه توسط لتو و همكاران در سال

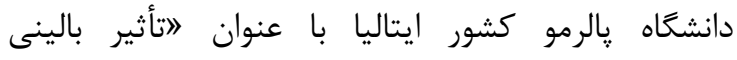
سيستاتين C كاتِيسين L و فولستاتين/اكتيوين A در

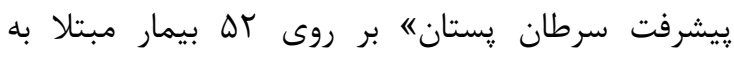

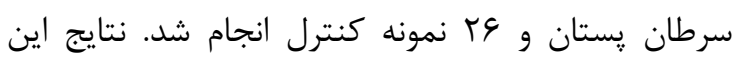
مطالعه نشان داد كه غلظت سيستاتين C سرمى در تروه بيماران مبتلا به سرطان بُستان با كروه افراد سالم تفاوت

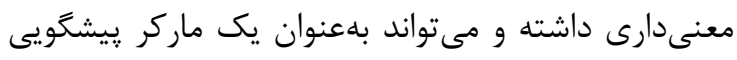

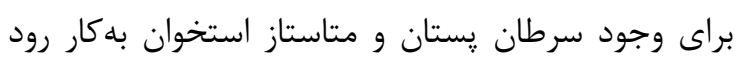

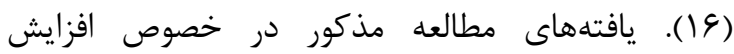

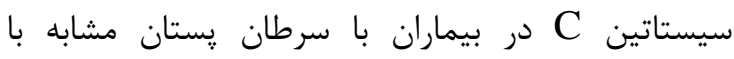

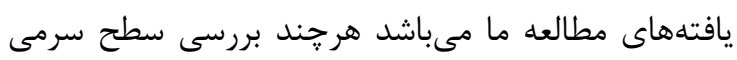

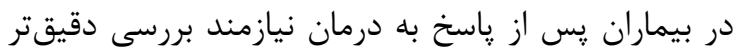

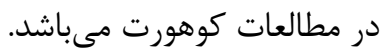

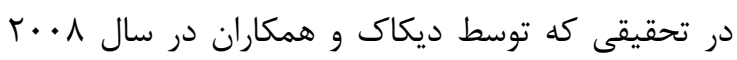

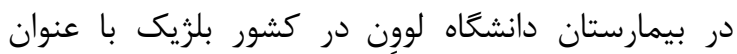

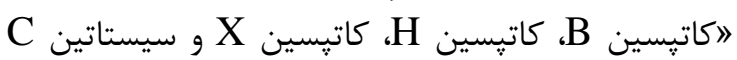

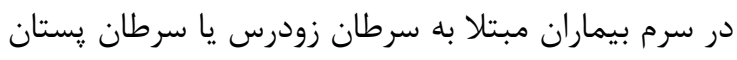

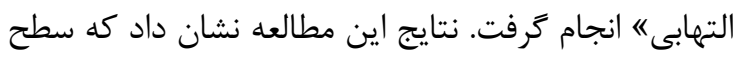

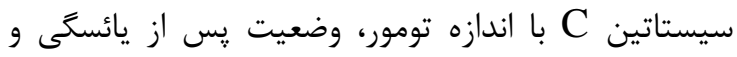

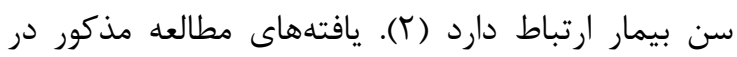

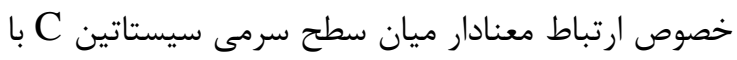

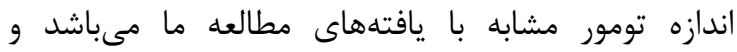

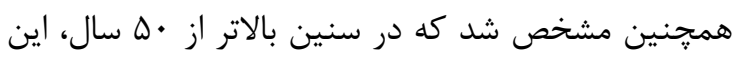

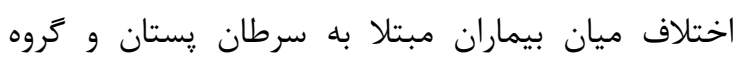

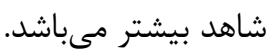
در مطالعهايى كه در سال هـ • • ب توسط ناداراجا و همكاران

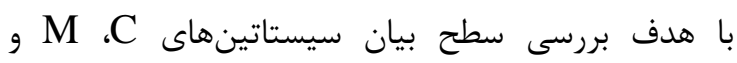

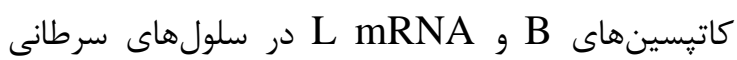
״ستان جداشده توسط ميكروديسكشن انجام شد. سطح و و يروتئين كاتيسين BRNA در نمونههاى سرطان يستان با استفاده از RT-PCR، وسترن بلات و روشهاى ايمونوهيستوشيميايى تعيين شد. 


$$
\begin{aligned}
& \text { نوآورى دانشكده يزشكى دانشعاه آزاد اسلامى مشهد و نيز }
\end{aligned}
$$

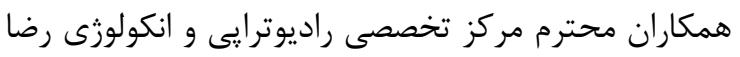

$$
\begin{aligned}
& \text { مشهد جهت حمايت از اين كار ابراز مى دارند. } \\
& \text { تعارض منافع } \\
& \text { نويسندًان اعلام مى دارند كه هيجَّونه تعارض منافعى در } \\
& \text { يزوهش حاضر وجود ندارد. }
\end{aligned}
$$

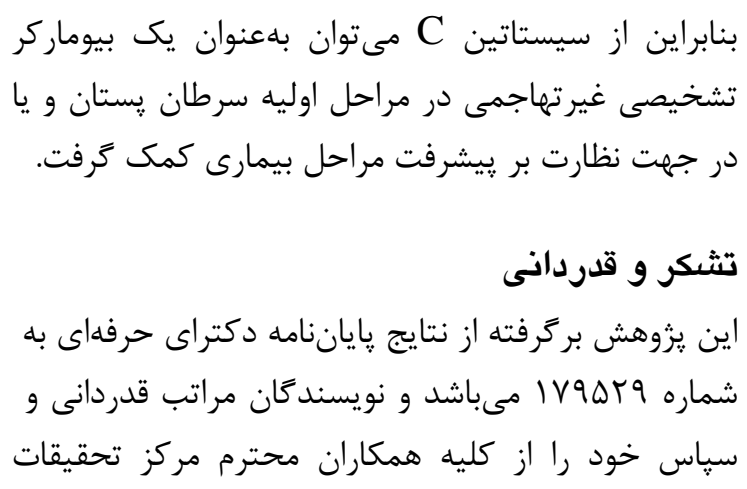

paradigm of the "common soil" hypothesis. In Seminars in Cancer Biology. 2021;72:4-10.

10. Enayatrad M, Amoori N, Salehiniya H. Epidemiology and trends in breast cancer mortality in Iran. Iranian Journal of Public Health. 2015; 44:430-1.

11. Akbari ME, Mozaffar M, Heidari A, Zirakzadeh H, Akbari A, Akbari M, et al. Recurrence and Survival Effect in Breast Conserving Surgery: What are the Predictive and/or Prognostic Factors? Iranian Journal of Cancer Prevention. 2011; 4:49-54.

12. Shankar A, Teppala S. Relationship between body mass index and high cystatin levels among US adults. The Journal of Clinical Hypertension. 2011;13(12):925-30.

13. Finney H, Bates CJ, Price CP. Plasma cystatin $\mathrm{C}$ determinations in a healthy elderly population. Archives of gerontology and geriatrics. 1999; 29(1):75-94.

14. Liu K, Zhang W, Dai Z, Wang M, Tian T, Liu $\mathrm{X}$, et al. Association between body mass index and breast cancer risk: evidence based on a dose-response meta-analysis. Cancer management and research. 2018; 10:143.

15. Kwon WS, Kim TS, Nahm CH, Moon Y, Kim JJ. Aberrant cystatin-C expression in blood from patients with breast cancer is a suitable marker for monitoring tumor burden. Oncology letters. 2018; 16(5):5583-90.

16. Leto G, Incorvaia L, Flandina C, Ancona C, Fulfaro F, Crescimanno M, et al. Clinical impact of cystatin C/cathepsin L and follistatin/activin A systems in breast cancer

9. Iacoviello L, Bonaccio M, de Gaetano G, Donati MB. Epidemiology of breast cancer, a 
progression: a preliminary report. Cancer investigation. 2016; 34(9):415-23.

17. Vigneswaran N, Wu J, Muller S, Zacharias W, Narendran S, Middleton L. Expression analysis of cystatin $\mathrm{C}$ and $\mathrm{M}$ in laser- capture microdissectioned human breast cancer cells-a preliminary study. Pathology-Research and Practice. 2005; 200(11-12):753-62

18. Leto G, Sepporta MV. The potential of cystatin $\mathrm{C}$ as a predictive biomarker in breast cancer. Expert Review of Anticancer Therapy. 2020; 20(12):1049-56. 